\title{
Heterogeneity of Human Melanoma-Associated Antigens Defined by Monoclonal Antibodies and Conventional Xenoantisera
}

\author{
Barry S. Wilson*, Neil E. Kay**, Kohzoh Imai***, and Soldano Ferrone \\ Department of Pathology and Surgery, College of Physicians und Surgeons, Columbia University, \\ 630 W. 168th Street, New York, NY 10032, USA
}

\begin{abstract}
Summary. Immunochemical analysis of cultured human melanoma cell detergent extracts and spent culture medium with conventional xenoantisera and monoclonal antibodies identified four types of 94,000 (94K) dalton molecules and two types of high-molecular-weight melanoma-associated antigens by the following characteristics: (1) association with other components, (2) mobility in SDS-PAGE under reducing and nonreducing conditions, (3) antigenicity, and (4) presence in spent culture medium. Conventional xenoantisera were found to contain antibody populations to antigenically distinct structures, some of which have similar apparent molecular weights. Immunodepletion studies showed that the antigenic determinant detected by the monoclonal antibody $225.28 \mathrm{~S}$ to a high-molecular-weight melanoma-associated antigen was expressed on a subpopulation of the antigens defined by the conventional xenoantiserum \#8995. These data prove that antibodies reactive with antigens of similar molecular weight cannot be assumed to identify the same structures, and indicate that tumor-associated antigens may be heterogeneous in the expression of antigenic determinants defined by monoclonal antibodies.
\end{abstract}

\section{Introduction}

A number of tumor-associated antigens have been identified in human melanoma cells with both conventional xenoantisera [for review, see 8] and monoclonal antibodies [4, 5, 10, 12, 13, $20,22-24]$. In many cases antigens of similar molecular weight and subunit structure have been described. Thus, Dippold et al. [5], Woodbury et al. [23], and Wilson et al. [22], using monoclonal antibodies, and Galloway et al. [9], using conventional xenoantisera, have described a single chain melanoma-associated antigen (MAA) having a molecular weight in the range 94,000-97,000 (94K-97K) daltons. Furthermore, Mitchell et al. [15], using a nnonoclonal antibody

Reprint requests should be addressed to $\mathrm{S}$. Ferrone

* Present address: Department of Pathology, University of Michigan Medical School, Ann Arbor, Michigan

* Visiting investigator from the Veterans Administration Hospital, Minneapolis, Minnesota

*** Visiting investigator from Sapporo Medical College (Japan).

Abbreviations used: MAA, melanoma-associated antigen; PBS, phosphate-buffered saline; NP40, nonidet P40; MoAb, monoclonal antibody; SDS-PAGE, sodium dodecyl sulfate polyacrylamide gel electrophoresis; 2-ME, 2-mercaptoethanol have described a $95 \mathrm{~K}$ dalton MAA, which is associated with three additional components having molecular weights of $116 \mathrm{~K}, 29 \mathrm{~K}$, and $26 \mathrm{~K}$ daltons, while Wilson et al. [20, 22], also using a monoclonal antibody, have identified a $94 \mathrm{~K}$ dalton glycopolypeptide which is associated with $75 \mathrm{~K}, 70 \mathrm{~K}$, and $25 \mathrm{~K}$ dalton structures. Also, Galloway et al. [9], using conventional xenoantisera, described a $240 \mathrm{~K}$ dalton spent medium MAA and, more recently, we characterized monoclonal antibodies immunoprecipitating a similar molecular weight glycopolypeptide from cultured melanoma cells $[16,20]$. Whether these various antibodies are recognizing the same or different antigenic structures and whether a determinant defined by a monoclonal antibody is expressed on all the molecules comprising a given type of MAA are areas of investigation critical to future progress in the field of tumor-associated antigens. The need for this information is felt among investigators in the melanoma field, as indicated by the organization of workshops to exchange monoclonal antibodies and compare their specificity and by a recent paper by Brown et al. [3] who, through immunodepletion experiments, have shown that the $97 \mathrm{~K}$ dalton glycoprotein recognized by their antibody is identical to the $95 \mathrm{~K}$ dalton glycoprotein identified by the monoclonal antibody of Dippold et al. [5].

In this paper we have addressed ourselves to these problems by using xenoantisera and monoclonal antibodies to determine the antigenic relationship among structures with a similar apparent molecular weight and we have assessed whether the determinants identified by the monoclonal antibodies are expressed by all the molecules of a given type of MAA. We have focused on $94 \mathrm{~K}$ dalton and high-molecular-weight antigens synthesized by cultured melanoma cells, since the former has been described in several reports and the latter appears to be restricted to melanoma $[16,20,22]$.

\section{Materials and Methods}

Cultured Human Cell Lines. Human cells in long-term culture were maintained in RPMI 1640 medium containing $10 \%$ calf serum. The growth characteristics and the histocompatibility antigenic profiles of the various cells used are reported elsewhere [20]. A confluent monolayer of melanoma cells (BwV) in a T-25 flask (Falcon Plastics, Cockeysville, MD) was intrinsically radiolabelled with $2 \mathrm{mCi}{ }^{3} \mathrm{H}$-glucosamine D- $\left[6-{ }^{3} \mathrm{H}(\mathrm{N})\right], 30 \mathrm{mCi} / \mathrm{mMole}$ (New England Nuclear, Boston, MA) according to the method described by Duksin and Bornstein [6]. The medium was removed and the monolayer was extensively washed with phosphate-buffered saline (PBS) 
before addition of $2 \mathrm{ml} 0.5 \%$ Nonidet P-40 (NP-40) detergent in PBS containing $10 \mu M$ of the proteolytic inhibitor, phenylmethylsulfonylfluoride. The resulting extract was cleared by centrifugation at $7,000 \mathrm{~g}$ and stored at $-20^{\circ} \mathrm{C}$.

Conventional Antisera. Antiserum \#8986 was from a rabbit immunized with somatic cell hybrids derived from the fusion of human melanoma cells with murine fibroblasts [11]; following absorption with cultured lymphoid cells this xenoantiserum reacted with both melanoma and carcinoma cells in binding assays. The xenoantiserum \#8995 to a high molecular weight MAA was produced by weekly injections of a $3 \mathrm{M} \mathrm{KCl} \mathrm{extract}$ from cultured human melanoma cells (M21) which had been bound to lentil lectin Sepharose [9]; following absorption with cultured lymphoid cells this xenoantiserum reacts with melanoma cells but does not react with carcinoma cells. The xenoantiserum \#8823 was from a rabbit immunized with human Ia-like antigens bound to an immunoadsorbent formed by reacting an NP40 extract of cultured B lymphoid cells Raji with Staphylococcus aureus Cowan I strain bacteria loaded with antibodies from a rabbit anti-Daudi cell xenoantiserum; the antiserum had been absorbed with cultured human $T$ cells (Molt-4) prior to reaction with the bacteria [19]. This xenoantiserum (\#8823) specifically reacted with Ia-like antigen-bearing cells in serological assays. A xenoantiserum to human plasma fibronectin was prepared according to the method of Engvall and Ruoslahti [7].

Monoclonal Antibodies (MoAb). The MoAbs 225.28S, $376.96 \mathrm{~S}$, and $465.12 \mathrm{~S}$, all IgG2a, were secreted by hybridomas constructed with the murine myeloma cells Sp 2/0-Ag 14 and splenocytes from BALB/c mice immunized with cultured human melanoma cells. Each hybridoma has been subcloned at least twice and has been propagated in vitro and in vivo. The $\mathrm{MoAb} 225.28 \mathrm{~S}$ specifically reacts with nevi, melanoma, and some skin cell carcinomas, while the MoAb 376.96S reacts with both melanomas and various carcinomas [20, 22]. The MoAb 465.12S identifies an antigen present in the cytoplasm of a large variety of normal and malignant cells $[20,22]$. The method of preparation and the serological and immunochemical characterization of the specificity of each monoclonal antibody have been described elsewhere $[12,16,20,22]$.

Indirect Immunoprecipitation and Sodium Dodecyl Sulfate Polyacrylamide Gel Electrophoresis (SDS-PAGE). Indirect immunoprecipitation was performed as described previously [1], except that protein A-Sepharose-4B was used in place of formalin-fixed bacteria, and pre-clearing of the NP-40 detergent cell extract was not necessary. For immunodepletion experiments, a ${ }^{3} \mathrm{H}$-glucosamine-labelled antigen preparation $(300 \mu \mathrm{l})$ was reacted three successive times for $2 \mathrm{~h}$ at $4^{\circ} \mathrm{C}$ with $30 \mu \mathrm{l}$ protein A-Sepharose $4 \mathrm{~B}$ coupled with either normal IgG (negative control depletion) or xenoantibodies. The remaining unreactive antigens were then separated into equal aliquots and tested for reactivity with the same antibody as was used for depletion (to insure its completeness) and with other antibodies of interest.

SDS-PAGE was performed in $80 \times 1.5 \mathrm{~mm}$ slab gels containing $7.5 \%$ polyacrylamide and the SDS buffer system of Laemmli [14]. The gels containing ${ }^{3} \mathrm{H}$-glucosamine-labelled antigens were processed for fluorography as described by Bonner and Laskey [2]. Human plasma fibronectin (220K), rabbit phosporylase a $(94,000)$, bovine serum albumin $(68,000)$, ovalbumin $(44,000)$, carbonic anhydrase $(29,000)$, and whale myoglobin $(17,000)$ were used as molecular weight standards.

\section{Results}

Identification of a Family

of Antigenically Distinct $94 \mathrm{~K}$ Dalton Molecules Synthesized and Shed by Melanoma Cells

The MoAb 376.96S, 465.12S and the polyclonal xenoantisera \#8823 and \#8986 all immunoprecipitated structures which when electrophoresed under reducing conditions gave apparent molecular weights of $94 \mathrm{~K}$ (Fig. 1). That these $94 \mathrm{~K}$ dalton structures may be different is suggested by the fact that the MoAb $465.12 \mathrm{~S}$ immunoprecipitates a $75 \mathrm{~K}$, a $70 \mathrm{~K}$, and a $25 \mathrm{~K}$ dalton structure in addition to the $94 \mathrm{~K}$ dalton molecule, and the $94 \mathrm{~K}$ dalton molecule detected by MoAb $376.96 \mathrm{~S}$ exhibits a much broader molecular weight heterogeneity than does the $94 \mathrm{~K}$ dalton molecules identified by the other antibody reagents. Furthermore, SDS-PAGE under nonreducing conditions showed that the $94 \mathrm{~K}$ dalton molecules detected by the xenoantiserum \#8823 exhibited a decrease in apparent molecular weight to $82 \mathrm{~K}$ daltons (Fig. 1), while the structures identified by MoAbs 465.12S, 376.96S and xenoantiserum \#8986 showed a decrease in apparent molecular weight to $86 \mathrm{~K}$ daltons. Interestingly, the $94 \mathrm{~K}$ dalton structure identified by xenoantiserum \#8986 resolves into two molecules under nonreducing conditions, one being similar to the type detected by the xenoantiserum \# 8823 and the other to the type detected by the $\mathrm{MoAb} 465.12 \mathrm{~S}$. This latter conclusion is consistent with the small amounts of the $75 \mathrm{~K}$ and $70 \mathrm{~K}$ dalton components immunoprecipitated by the xenoantiserum \#8986. Additional evidence that melanoma cells synthesize three different $94 \mathrm{~K}$ dalton molecules was obtained from sequential immunodepletion studies. A ${ }^{3} \mathrm{H}$-glucosamine-labelled NP40 melanoma

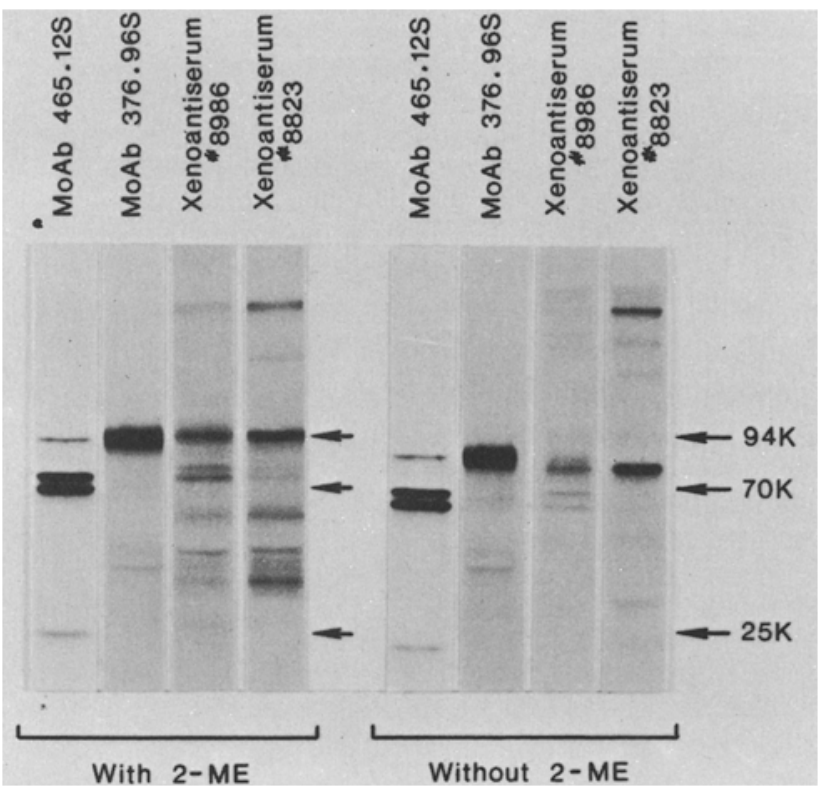

Fig. 1. SDS-PAGE analysis of human melanoma cell-derived $94 \mathrm{~K}$ dalton molecules defined by monoclonal antibodies and conventional xenoantisera. A ${ }^{3} \mathrm{H}$-glucosamine-labelled $\mathrm{BwV}$ melanoma cell NP40 extract was immunoprecipitated with antibodies bound to Sepharose $4 \mathrm{~B}$, after which the eluted antigens were boiled in the presence or absence of 2-mercaptoethanol and then subjected to SDS-PAGE 
cell extract exhaustively depleted of all the $94 \mathrm{~K}$ dalton molecules reactive with the MoAb 465.12S still contained the 94K dalton molecules detected with MoAb 376.96S and with xenoantisera \#8823 and \#8986 (Fig. 2); conversely, depletion of a similar radiolabelled melanoma cell extract with the MoAb $376.96 \mathrm{~S}$ did not effect the $94 \mathrm{~K}$ dalton structures detectable by MoAb 465.12S and by the xenoantiserum \#8823 and \#8986 (data not shown). The xenoantisera were not used for immunodepleting the labelled cell extracts, since these reagents are only operationally specific and may contain small amounts of antibodies to all the various $94 \mathrm{~K}$ dalton molecules, resulting in a false interpretation of antigenic similarity.

Immunoprecipitation of the ${ }^{3} \mathrm{H}$-glucosamine-labelled spent culture medium from melanoma cells with the various antibodies to the $94 \mathrm{~K}$ dalton structures was performed to determine whether these structures are shed by melanoma cells (Fig. 3). The MoAb 376.96S occasionally detected a small amount of $94 \mathrm{~K}$ component in the spent medium of cultured melanoma cells, the xenoantiserum \#8823 reacted with fibronectin while the MoAb 465.12 and the xenoantiserum \#8986 immunoprecipitated a major $94 \mathrm{~K}$ and a minor $72 \mathrm{~K}$ dalton structure. Immunodepletion experiments showed that the MoAb 465.12 and the xenoantiserum \#8986 each reacts with the same population of $94 \mathrm{~K}$ dalton molecules present in the spent medium of ${ }^{3} \mathrm{H}$-glucosamine-labelled melanoma cells (Fig. 4). It should be noted that the minor $72 \mathrm{~K}$ dalton structure detected by MoAb 465.12S and xenoantiserum \#8986 is not easily identified in some melanoma cell lines, such as Colo 38 and M21. Furthermore, examination of unfractioned ${ }^{3} \mathrm{H}$-glu- cosamine spent media under reducing and nonreducing conditions revealed a fourth $94 \mathrm{~K}$ dalton structure previously undetected (Fig. 3), which exhibits an increased apparent molecular weight under nonreducing conditions, suggesting that in its native state it is disulfide-linked to a small-molecular-weight polypeptide.

\section{Identification of Antigenically Distinct High-Molecular-Weight Melanoma-Associated Antigens Synthesized and Shed by Melanoma Cells}

The monoclonal antibodies $225.28 \mathrm{~S}$ and the xenoantiserum \#8995 both immunoprecipitate two components from ${ }^{3} \mathrm{H}$-glucosamine-labelled melanoma cells BwV (Fig. 5). One component at $280 \mathrm{~K}$ daltons exhibits a slightly higher apparent molecular weight than melanoma $\mathrm{BwV}$ fibronectin, while the other structure is very large and can barely penetrate the top of the gel. The molecular weight of the latter component will be referred to as $>440 \mathrm{~K}$ daltons (nonreduced human plasma fibronectin) until appropriate molecular weight determinations can be done. The MoAb $225.28 \mathrm{~S}$ is unable to bind all the $280 \mathrm{~K}$ and $>440 \mathrm{~K}$ dalton molecules reacting with the xenoantisera \#8995, since the latter can still immunoprecipitate the high-molecular-weight structures from a cell extract completely depleted of such molecules reactive with the monoclonal antibody (Fig. 6). These data indicate that the antigenic determinant detected by the MoAb $225.28 \mathrm{~S}$ is not present on all the molecules comprising the $280 \mathrm{~K}$ and $>440 \mathrm{~K}$ dalton high-molecular-weight MAA system.

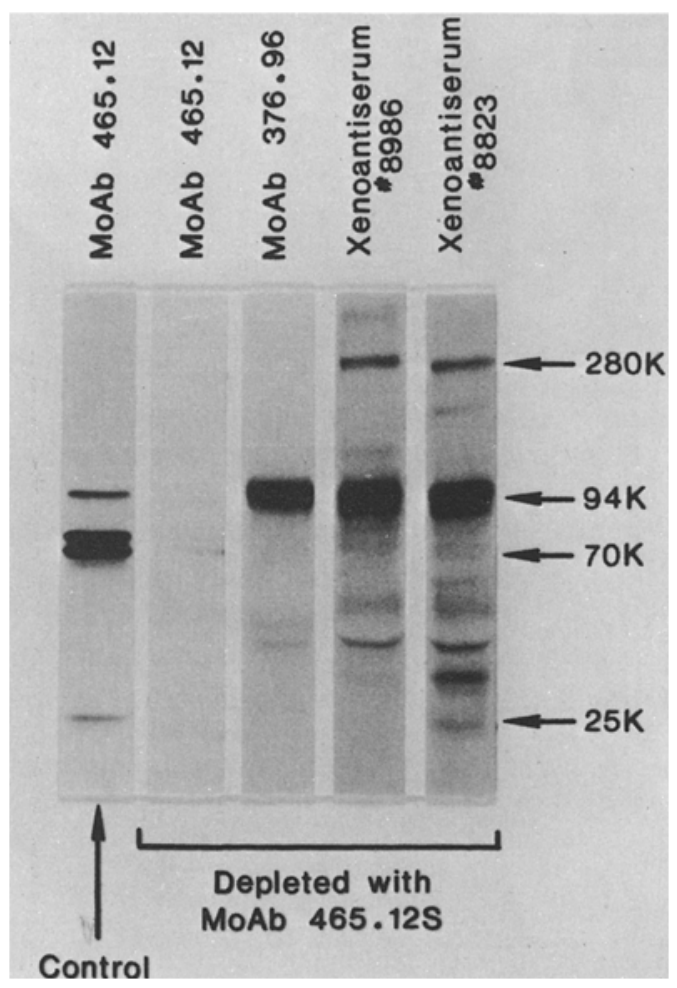

Fig. 2. Sequential immunodepletion analysis of $94 \mathrm{~K}$ dalton molecules synthesized by melanoma cells. A ${ }^{3} \mathrm{H}$-glucosamine-labelled $\mathrm{BwV}$ melanoma cell NP40 extract was exhaustively immunodepleted with normal human IgG Sepharose 4B or Sepharose 4B loaded with MoAb $465.12 \mathrm{~S}$. The supernatant was immunoprecipitated with xenoantibodies and then subjected to SDS-PAGE under reducing conditions ( $2 \%$ 2-mercaptoethanol)

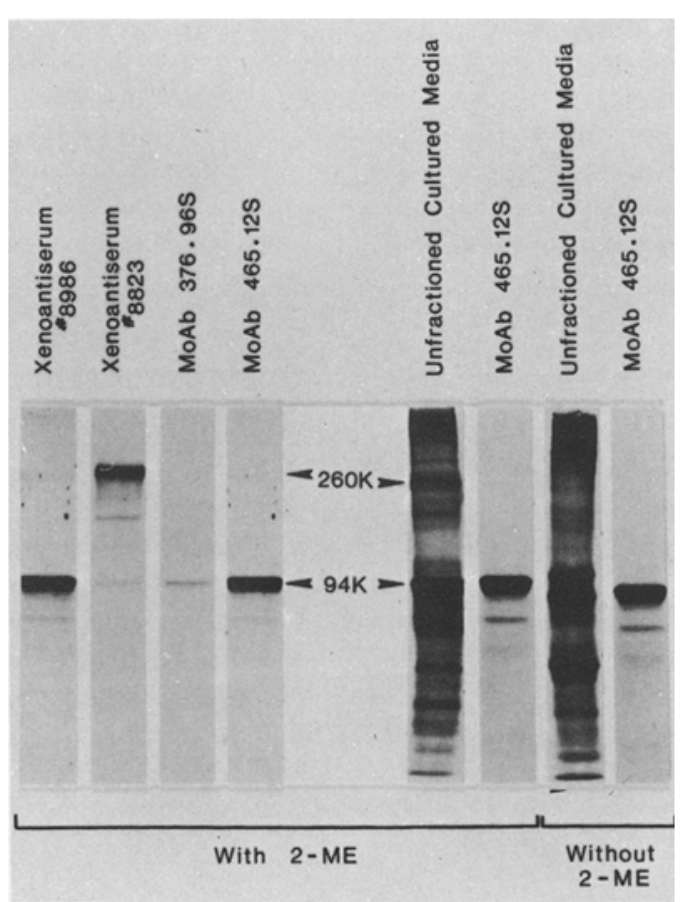

Fig. 3. SDS-PAGE analysis of $94 \mathrm{~K}$ dalton molecules shed by cultured human melanoma cells. Spent culture medium from ${ }^{3} \mathrm{H}$-glucosamine-labelled $\mathrm{BwV}$ melanoma cells was immunoprecipitated with xenoantibodies, after which the eluted antigens were boiled in the presence or absence of 2-mercaptoethanol and then analyzed by SDS-PAGE. Unfractionated ${ }^{3} \mathrm{H}$-glucosamine spent culture medium was from $\mathrm{BwV}$ melanoma cells. 


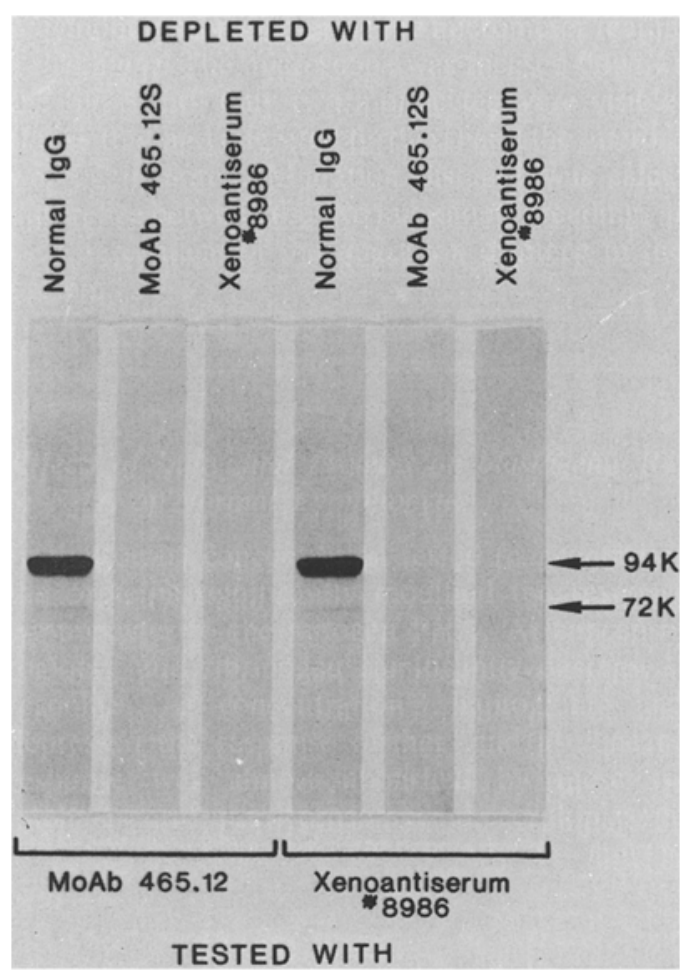

Fig. 4. Distribution of the antigenic determinant detected by MoAb $465.12 \mathrm{~S}$ on $94 \mathrm{~K}$ dalton molecules detected with the xenoantiserum \#8986. A ${ }^{3} \mathrm{H}$-glucosamine-labelled preparation of $\mathrm{BwV}$ melanoma spent culture medium was exhaustively immunodepleted by sequential reactions with normal human IgG Sepharose 4B or xenoantibodies bound to Sepharose $4 \mathrm{~B}$. The remaining labelled antigens were immunoprecipitated by xenoantibodies bound to Sepharose $4 \mathrm{~B}$, and then subjected to SDS-PAGE under reducing conditions

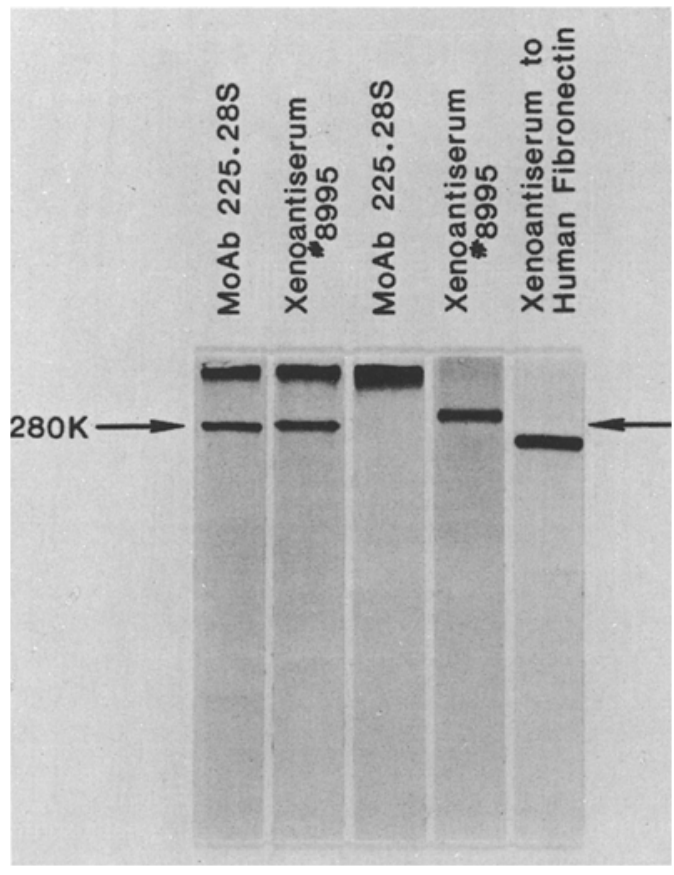

When spent medium of ${ }^{3} \mathrm{H}$-glucosamine-labelled cultured melanoma cells is used as an antigen source, the $\mathrm{MoAb}$ $225.28 \mathrm{~S}$ reacts with a very large structure seen at the top of the gel $(>440 \mathrm{~K})$, while the xenoantiserum \#8995 reacts with a component of approximately $300 \mathrm{~K}$ daltons (Fig. 5). Even though the xenoantiserum detects the same high-molecular-weight cellular antigen identified by the monoclonal antibody, a $>440 \mathrm{~K}$ dalton molecule was not immunoprecipitated from the spent culture medium by xenoantiserum \#8995, because the amount of labelled antigens used and the exposure time in fluorography were not sufficient to detect this component. Althouth we have been unable to repeat this experiment with the appropriate conditions because the xenoantiserum \#8995 is now unavailable, we have seen that other xenoantisera which immunoprecipitate the $280 \mathrm{~K}$ and $>440 \mathrm{~K}$ dalton cellular structures will also identify the $>440 \mathrm{~K}$ dalton media molecule under the appropriate conditions.

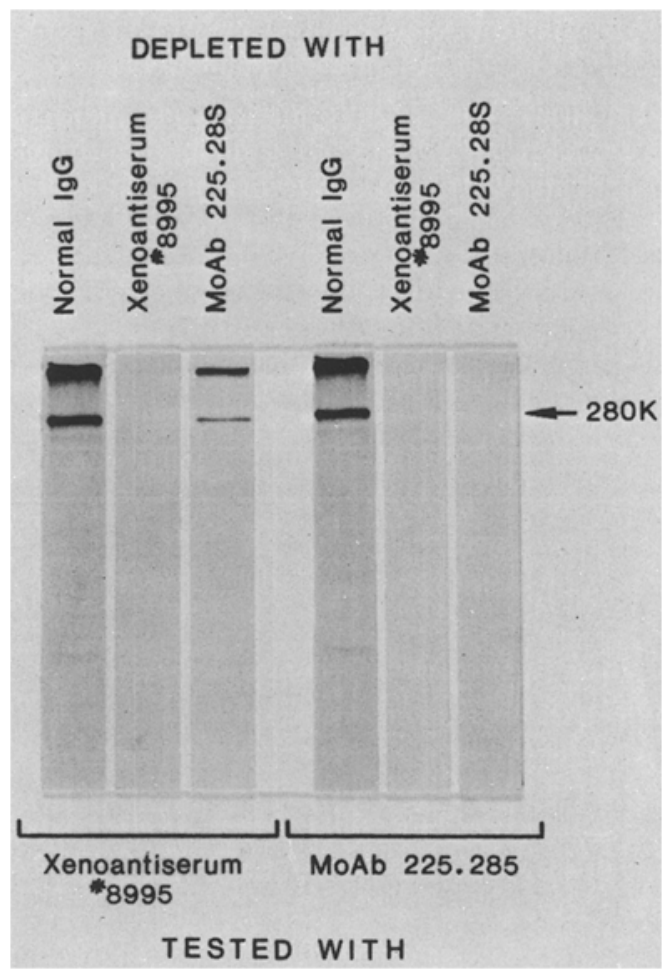

Fig. 6. Distribution of the antigenic determinant detected by MoAb $225.28 \mathrm{~S}$ on the high-molecular-weight antigens detected by xenoantiserum \#8995. A ${ }^{3} \mathrm{H}$-glucosamine-labelled BwV melanoma cell NP40 extract was exhaustively immunodepleted by sequential reaction with normal human IgG Sepharose 4B or xenoantibodies bound to Sepharose 4B. The remaining labelled antigens were immunoprecipitated by xenoantibodies bound to Sepharose $4 B$ and then subjected to SDS-PAGE under reducing conditions

Fig. 5. SDS-PAGE analysis with the monoclonal antibody $225.28 \mathrm{~S}$ and with the conventional xenoantiserum \#8985 of high-molecular-weight MAA synthesized and shed by melanoma cells. An NP40 extract (first and second lane from the left) or the spent culture medium (third, fourth and fifth lane) of ${ }^{3} \mathrm{H}$-glucosamine-labelled BwV melanoma cells was immunoprecipitated with the insolubilized xenoantibodies, after which the eluted antigens were boiled in the presence of 2-mercaptoethanol and analyzed by SDS-PAGE 


\section{Discussion}

Immunochemical analysis of human melanoma cells with conventional xenoantisera and monoclonal xenoantibodies has identified several antigenically distinct structures that have similar apparent molecular weights. Four types of $94 \mathrm{~K}$ dalton molecules and two types of high-molecular-weight antigens were identified by the following characteristics: (1) association with other components, (2) mobility in SDS-PAGE under reducing and nonreducing conditions, (3) antigenicity, and (4) presence in spent culture media. The MoAb 376.96S reacts with a single $94 \mathrm{~K}$ dalton molecule present on the plasma membrane and inconsistently found in spent media, while the MoAb 465.12 and the xenoantiserum \#8986 immunoprecipitate cellular $75 \mathrm{~K}, 70 \mathrm{~K}$, and $25 \mathrm{~K}$ dalton components in addition to a major $94 \mathrm{~K}$ dalton and a minor $72 \mathrm{~K}$ dalton structure which are readily shed into spent culture medium. Immunodepletion studies showed that the spent media $94 \mathrm{~K}$ dalton molecule detected by MoAb 465.12S is the same structure as was identified with conventional xenoantisera and already described in a previous study [9]. The spent media $72 \mathrm{~K}$ dalton molecule was not identified in the previous study since it is readily detectable in media from only some melanoma cell lines, which were not included in the earlier study. The xenoantiserum \#8823 reacts with a cellular 94K dalton molecule distinct from the ones detected by our monoclonal antibodies, while a fourth $94 \mathrm{~K}$ dalton molecule was detected in spent culture medium and was probably disulfide-bridged in its native state with a small-molecular-weight protein. We presently have no antibodies reactive with this $94 \mathrm{~K}$ dalton media molecule.

In regard to high-molecular-weight antigens, the $\mathrm{MoAb}$ 225.28S and the xenoantiserum \#8995 recognize two glycosylated structures from detergent extracts of cultured melanoma cells, one at $280 \mathrm{~K}$ daltons and the other $>440 \mathrm{~K}$ daltons, while only the $>440 \mathrm{~K}$ dalton structure was detectable in the spent culture medium. In addition, the xenoantiserum $\# 8995$ detects a $300 \mathrm{~K}$ dalton molecule present in spent culture medium but not in labelled cell extracts. The latter structure is either not solubilized by treatment with nonionic detergent (NP40) or is rapidly transported outside the cells and into the medium following synthesis. The media molecule detected by xenoantiserum \#8995 was previously estimated to be $240 \mathrm{~K}$ [9] rather than $300 \mathrm{~K}$ daltons, since melanoma-derived fibronectin used as a molecular weight standard was assumed to have the same apparent molecular weight as plasma fibronectin. We have recently found that melanoma-derived fibronectin has a $40 \mathrm{~K}$ dalton greater apparent molecular weight than plasma fibronectin [21], hence increasing the molecular weight estimation of the spent medium MAA from $240 \mathrm{~K}$ daltons to approximately $300 \mathrm{~K}$ daltons.

The comparison of conventional xenoantisera with monoclonal antibodies clearly illustrates the limitations inherent in the former reagent. The conventional xenoantisera, being only operationally monospecific, may contain antibodies to more than a single antigenic system and this can be very misleading since there are several types of distinct antigenic structures having very similar apparent molecular weights. Thus, in the case of the xenoantiserum \#8995, its reactivity with a $280 \mathrm{~K}$ dalton cellular antigen and a $300 \mathrm{~K}$ dalton media molecule suggested that these structures were antigenically related rather than coincidently identified by two different types of antibodies in this antiserum; however, the results with monoclonal antibodies clearly show that the xenoantiserum contains two different types of antibodies. Another problem is that the specificity of xenoantisera may vary from bleeding to bleeding, resulting in limited supplies of a particular reagent. In fact, we have exhausted our supply of several xenoantisera, including \#8995, and have tried unsuccessfully to produce other reagents with similar specificities.

When we assessed the distribution of antigenic determinants detectable by monoclonal antibodies in the population of antigens defined with a conventional xenoantiserum, we found that the determinant detected by MoAb $465.12 \mathrm{~S}$ was present on all the $94 \mathrm{~K}$ dalton molecules, while the determinant defined by MoAb 225.28S is detectable on only a subpopulation of the high-molecular-weight antigens. Therefore, the family of $>440 \mathrm{~K} / 280 \mathrm{~K}$ dalton molecules is heterogeneous in the expression of determinants defined by monoclonal antibodies. These results parallel our previous experiences with monoclonal antibodies to HLA-A,B,C and human Ia-like antigens $[17,18]$, suggesting that the high-molecular-weight MAA may be polymorphic. It will be interesting to determine whether the molecules carrying antigenic determinants detected by the monoclonal antibodies to the high-molecular-weight MAA are expressed on all the cells of a melanoma population and whether expression of a particular antigenic determinant is associated with a certain clinical course of this disease.

Acknowledgements. This work was supported by grants AI 19189, CA 32609, CA 32619, CA 32634, and CA 32635 from the National Institutes of Health. The skillful secretarial assistance of Ms Ellen Schmeding is recognized.

BSW was supported by a 'Special Felloship' from the Leukemia Society of America, and KI was the recipient of a public health service Fogarty International Research Fellowship award (5 FO5 TWO2817-02).

\section{References}

1. Allison JP, Belvedere M, Reisfeld RA, Pellegrino MA, Ferrone S (1978) Serologic and immunochemical characterization of HLA-A9 xenoantisera. J Immunol 121: 579

2. Bonner WM, Laskey RA (1974) A film detection method for Tritium-labelled proteins and nucleic acids in polyacrylamide gels. Eur J Biochem 46:83

3. Brown JP, Nishiyama K, Hellstrom I, Hellstrom KE (1981) Structural characterization of human melanoma-associated antigen $\mathrm{p} 97$ with monoclonal antibodies. J Immunol 127: 539

4. Carrel S, Accolla RS, Carmagnola AL, Mach JP (1980) Common human melanoma-associated antigen(s) detected by monoclonal antibodies. Cancer Res 40:2523

5. Dippold WG, Lloyd KO, Li LTC, Ikeda H, Oettgen HF, Old LJ (1980) Cell surface antigens of human malignant melanoma: Definition of six antigenic systems with mouse monoclonal antibodies. Proc Natl Acad Sci USA 77:6114

6. Duksin D, Bornstein P (1976) Impaired conversion of procollagen to collagen by fibroblasts and bone treated with tunicamycin, an inhibitor of protein glycosylation. J Biol Chem 252:955

7. Engvall E, Ruoslahti E (1977) Binding of soluble form of fibroblast surface protein, fibronectin, to collagen. Int J Cancer 20: 1

8. Ferrone S, Pellegrino MA (1979) Serological detection of human melanoma-associated antigens. In: Immunodiagnosis of cancer. Deckker, New York, p 588

9. Galloway DR, McCabe RP, Pellegrino MA, Ferrone S, Reisfeld RA (1981) Tumor-associated antigens in the spent media of human melanoma cells: Immunochemical characterization with xenoantisera. J Immunol 126:62

10. Imai K, Molinaro GA, Ferrone S (1980) Monoclonal antibodies to human melanoma-associated antigens. Transplant Proc 12:380 
11. Imai K, Galloway DR, Ferrone S (1981a) Serological and immunochemical analysis of the specificity of the xenoantiserum 8986 elicited with hybrids between human melanoma cells and murine fibroblasts. Cancer Res 41:1028-1033

12. Imai $\mathrm{K}, \mathrm{Ng} \mathrm{AK}$, Ferrone $\mathrm{S}$ (1981b) Characterization of monoclonal antibodies to human melanoma-associated antigens. J Natl Cancer Inst 66: 489

13. Koprowski H, Steplewski A, Herlyn D, Herlyn M (1978) Study of antibodies against human melanoma produced by somatic cell hybrids. Proc Natl Acad Sci USA 75:3405

14. Laemmli UK (1970) Cleavage of structural proteins during the assembly of the head of bacteriophage T4. Nature 227:680

15. Mitchell KF, Fuhrer JP, Steplewski Z, Koprowski H (1980) Biochemical characterization of human melanoma cell surfaces: Dissection with monoclonal antibodies. Proc Natl Acad Sci USA $77: 7287$

16. Natali PG, Imai K, Wilson BS, Bigotti A, Cavaliere R, Pellegrino MA, Ferrone S (1981) Structural properties and tissue distribution of the antigen recognized by the monoclonal antibody $653.40 \mathrm{~S}$ to human melanoma cells. J Natl Cancer Inst 67:591

17. Quaranta V, Pellegrino MA, Ferrone S (1981) Serological and immunochemical characterization of the specificity of four monoclonal antibodies to distinct antigenic determinants expressed on subpopulations of human Ia-like antigens. J Immunol 126: 548

18. Russo C, Pellegrino MA, Ng AK, Wilson BS, Ferrone S (1982) Antigenic constitution of HLA-A,B,C molecules: Immunochemical analysis with monoclonal antibodies. In: Ferrone S, Solheim
BG (eds) HLA typing: Methodology and clinical relevance. CRC Press, Boca Raton (in press)

19. Wilson BS, Indiveri F, Pellegrino MA, Ferrone S (1979) Production and characterization of DR xenoantisera: Use for detection of serum DR antigens. J Immunol 122:1967

20. Wilson BS, Imai K, Natali PG, Ferrone S (1981) Distribution and molecular characterization of a cell-surface and a cytoplasmic antigen detectable in human melanoma cells with monoclonal antibodies. Int J Cancer 28: 293

21. Wilson BS, Ruberto G, Ferrone S (1981) Sulfation and molecular weight of fibronectin shed by human melanoma cells. Biochem Biophys Res Commun 101: 1047

22. Wilson BS, Imai K, Natali PG, Cavalieri R, Pellegrino MA, Ferrone S (1982) Antigenic profile of human melanoma cells: Analysis with monoclonal antibodies. In: Ferrone S, Reisfeld RA (eds) Melanoma antigens and antibodies. Plenum Press, New York London

23. Woodbury RG, Brown JP, Yeh MY, Hellstrom I, Hellstrom KE (1980) Identification of a cell-surface protein, p 97, in human melanomas and certain other neoplasms. Proc Natl Acad Sci USA $77: 2183$

24. Yeh MY, Hellstrom I, Brown JP, Warner GA, Hansen JP, Hellstrom KE (1979) Cell surface antigens of human melanoma defined by monoclonal antibody. Proc Natl Acad Sci USA $76: 2927$

Received September 22, 1981/Accepted February 10, 1982 